FYLYPPOVA L. V. The development of students' self-organization in the study of chemical disciplines.

The article describes how reflection can lead to a process of self-organization in students, which is important for further development and for self-determination in the world. To become more competitive in the labor market and in the world. The main aspects of the distribution of one's own time during the student's educational activity are described in detail. It is the proper allocation of free time that helps the student to learn to organize himself. It examines in detail the main components through which you can develop and build skills for self-organization. It describes the main task in the formation of self-organizing skills that occur only under the action of reflective actions, and this is the main thing in the study of chemical disciplines to understand their own actions. The criteria of reflexivity, which are closely related to the student's independent work in higher education, are considered. There are two main aspects that underlie the student's independent activity during the educational process. The "gap situation" that causes students' reflective actions to resolve the problem independently is discussed in detail. This situation allows you to consolidate the acquisition of new knowledge, while at the same time recalling the skills that a student already has and projecting new knowledge into another area of knowledge. The group of chemical competencies that is inherent to students of pharmaceutical faculties is given. It is these competencies that are fundamental to the study of vocational-oriented disciplines for students of pharmaceutical higher education.

Keywords: self-organization, self-determination, "gap situation", independent activity, chemical competences.

DOI: https://doi.org/10.31392/NZ-npu-144.2019.26

УДК 378.147-057.875[34:61]616-051:005.336.2

Хміль І. Ю.

\title{
ПРОБЛЕМА ФОРМУВАННЯ ПРЕДМЕТНОЇ КОМПЕТЕНТНОСТІ МАЙБУТНІХ ЛІКАРІВ У ПЕДАГОГІЧНІЙ ТЕОРІї
}

У статті проведено аналіз наукових праиць вчених з проблеми формування предметної компетентності майбутніх лікарів. На основі вивчення наукових робіт показані досягнення, недоліки $i$ перспективи порушеної проблеми. Охарактеризовано компетентність як спроможність особистості сприйлати та відповідати на індивідуальні та соціальні потреби, комплекс ставлень, иінностей, особистісну якість яка трунтується на знаннях, уміннях.

Предметну компетентність розглянуто як інтегрований результат навчальної діяльності студентів, складову його саморозвитку і самовдосконалення, важсливий засіб підвищення професійної готовності спечіаліста. Зазначимо, що специфіка лікаря висуває особливі вимоги до рівня підготовки студентів у майбутній професійній діяльності, які з найбільшою ймовірністю зможуть успішно освоӥти сучасні медичні знання $і$ пращювати у галузі тривалий час. Наголошено, що знання й уміння $з$ правознавства є фундаментом правової предметної компетентності майбутнього лікаря, оскільки без уявлень $і$ знань про право не може формуватися готовність слідувати його нормам, иіннісне ставлення до нього та здатність чинити значимі правові діяння.

Предметну компетентність можна окреслити як сукупність набутих майбутнім лікарем знань $з$ правознавства, умінь, особистісних якостей, необхідних для виконання певних дій з метою розв'язання проблем, ситуачій згідно приписів норм права.

Ключові слова: компетентність, предметна компетентність, освіта, студент, майбутній лікар, правознавство, медичне правознавство. 
Національна система освіти зазнає значних зрушень, пов'язаних із інтеграційними процесами, глобалізацією та орієнтацією освіти на європейські й світові стандарти. Означені процеси зумовлюють впровадження до змісту сучасної освіти компетентнісного підходу, який спрямований на формування у майбутніх фахівців базових і предметних компетентностей. Відтак професійна підготовка лікаря $\epsilon$ складною поетапною системою управління його професійним розвитком, формування у нього здатності до вирішення завдань щодо охорони здоров'я.

Застосування компетентнісного підходу в освітню практику України були предметом розгляду таких науковців як Н. Бібік, О. Локшиної, О. Овчарук, О. Павленко, Л. Паращенко, О. Пометун, О. Савченко та ін. До проблеми компетентностей особистості звертаються такі вчені, як Н. Босак, О. Вознюк, І. Дроздова, О. Мамчич, М. Пентилюк, Н. Тализіна, В. Тернопільська [13; 14; 15; $16 ; 19 ; 20]$, Л. Шевчук тощо. Питання фрормування предметних компетентностей у своїх працях досліджували А. Будас, Н. Писеменна, Л. Петько [7; 8; 9; 20], О. Пишко та ін.

Водночас аналіз психолого-педагогічної літератури свідчить про недостатню розробку теоретичних засад формування предметної компетентності майбутніх лікарів, що негативно позначається на процесі їхньої профресійної підготовки.

Метою статmi $\epsilon$ аналіз проблеми фрормування предметної компетентності майбутніх лікарів у педагогічній науці.

Науковці предметну компетентність розглядають як інтегрований результат навчальної діяльності майбутніх фахівців, складову їх саморозвитку і самовдосконалення, важливий засіб підвищення професійної готовності спеціаліста.

У контексті вивчення теоретичних засад проблеми однією з основних категорій компетентнісного підходу є "компетентність". У Національній рамці кваліфікацій (2011) "компетентність" трактується як здатність особи до виконання певного виду діяльності, що виражається через знання, розуміння, уміння, цінності, інші особисті якості. Поняття "компетентність" відповідно до Міжнародного департаменту стандартів для навчання, досягнення та освіти [18] визначається як спроможність кваліфіковано проводити діяльність, виконувати завдання або роботу. При цьому поняття компетентності містить у собі знання, вміння, навички, ставлення, що дають змогу особистості ефективно діяти або виконувати ті чи інші функції, спрямовані на досягнення певних стандартів у професійній галузі або конкретній діяльності.

Важливо наголосити, що у наукових дослідженнях європейської системи освіти “компетентність" трактується дослідниками як спроможність особистості сприймати та відповідати на індивідуальні та соціальні потреби, комплекс ставлень, цінностей, знань і навичок. У проекті TUNING (Гармонізація освітніх структур у Європі) компетентності являють собою динамічне поєднання когнітивних та метакогнітивних вмінь та навичок, знань та розуміння, міжособистісних, розумових та практичних вмінь та навичок і етичних 
цінностей. Компетентності формуються в різних навчальних дисциплінах і оцінюються на різних етапах програми, а їх розвиток $є$ метою освітніх програм [2, c. 98].

Як бачимо компетентність містить у собі, крім професійних знань, умінь і навичок, такі якості, як ініціатива, співробітництво, здатність працювати в команді, соціально-комунікативні уміння.

За І. Зимньою, “компетентність” розглядається як актуальна, сорормована особистісна якість, яка ґрунтується на знаннях; інтелектуально і особистісно обумовлена соціально-професійна характеристика людини [3]. Вчена визначає компоненти, що включає компетентність: а) готовність до прояву цієї властивості в діяльності, поведінці людини; б) знання засобів, способів, програм виконання дій, рішення соціальних і професійних завдань, дотримання правил і норм поведінки, що складають зміст компетенцій; в) досвід реалізації знань, тобто уміння, навички; г) ціннісно-смислове ставлення до змісту компетенції, її особистісна значущість; д) емоційновольова регуляція як здатність адекватно до ситуацій соціальної та професійної взаємодії виявляти й регулювати прояви компетентності.

Продуктивними для нашого дослідження виявилися положення Т. Маслової “...поняття компетентності пов'язане, перш за все, саме 3 діяльністю, із здатністю виконувати певні професійні дії, в основі якої лежать необхідні професійні знання та вміння... Компетентність передбачає наявність у людини внутрішньої мотивації до якісного виконання всіх професійних завдань, наявність професійних цінностей. Компетентний спеціаліст виходить за межі предмета своєї професії, має певний творчій потенціал саморозвитку. В основі розвитку компетентності лежить культура самовизначення (здатність і готовність до самовизначення, самореалізації, саморозвитку). Професійний розвиток, зокрема, означає, що спеціаліст створює щось нове у своїй професії, хай навіть у невеликих масштабах (наприклад розробляє новий прийом, метод тощо). Він бере відповідальність за свої рішення, визначає мету, ґрунтуючись на власних поглядах та переконаннях" [6, с. 59].

Однак, дослідники Л. Цімашкова та Е. Шилова (2000) дають більш широке трактування терміну “компетентність". Компетентність - це сукупність узгоджених ціннісних орієнтацій, особистісних якостей, практичних умінь й реальної поведінки, що виявляється в ситуаціях взаємодії. Загалом, компетентність виявляється у знаннях, цінностях та уміннях особистості.

Ю. Татур визначає “компетентність спеціаліста з вищою освітою”, як вияв ним на практиці прагнення та здатності (готовність) реалізувати свій потенціал (знання, уміння, досвід, особистісні якості та ін.) для успішної творчої (продуктивної) діяльності в професійній і соціальній сфрерах, усвідомлюючи її соціальну значущість, особисту відповідальність за результати цієї діяльності, необхідність її постійного удосконалення [12, с. 22].

Підкреслимо дослідження С. Бондар, щодо компетентності як “здатності особистості діяти. Але жодна людина не діятиме, якщо вона особисто не зацікавлена в цьому. Природа компетентності така, що вона може 
проявлятися лише в органічній єдності з цінностями людини, тобто в умовах глибокої особистісної зацікавленості в даному виді діяльності... Отже, цінності $€$ основою будь-якої компетентності” [1, с. 9].

С. Гончаренко характеризує компетентність як "сукупність знань і умінь, необхідних для ефективної професійної діяльності: вміння аналізувати, передбачати наслідки діяльності, використовувати інфоормацію" [11, с. 149]. Отже, компетентність $€$ інтегративною якістю особистості та виявляється у їі готовності здійснювати певну професійну діяльність цілісно.

У дослідженнях І. Єліної (1999) та Г. Копил (2007) компетентність розглядається з декількох точок зору. Перша відображає позицію суб'єкта праці: взаємовідповідність покликання і визнання профеесіонала на державній службі. Друга розкриває їі психологічну структуру, згідно з якою професійна компетентність - це єдність трьох компонентів: операційного, мотиваційного і рефрлексії. Компонент рефлексії, по суті, виконує функції зворотних зв'язків в оцінці результату діяльності і самоконтролю суб'єкта праці. Сфрормульована й обґрунтована критерійна система оцінки профресійної компетентності базується на принципах нормативності складу і послідовності фраз алгоритму діяльності, векторного моделювання алгоритму діяльності, ізоморфності фраз діяльності на їі різних рівнях. Згідно з даним підходом рівень профресійної компетентності оцінюється головним чином за професійними здібностями, алгоритмами і якістю виконаної діяльності.

Компетентність $є$ інтегральним утворенням особистості й залежить від ії зусиль, саморозвитку. Означений феномен інтегрує в собі гностичний (знання), практичний (способи діяльності, готовність до діяльності) та ціннісний (наявність певних цінностей) аспекти.

У загальній структурі системи компетентностей людини вчені виокремлюють: 1) ключові компетентності (міжпредметні, базові або надпредметні компетентності); 2) загальногалузеві (формуються впродовж засвоєння змісту тієї чи іншої освітньої галузі протягом всього терміну навчання); 3) предметні (формуються під час вивчення конкретної навчальної дисципліни протягом визначеного часу).

В “Енциклопедії освіти" (2008, с. 128) визначаються: 1) ключові (надпредметні базові) компетентності як такі, що опираються на пізнавальні процеси і виявляються у різних контекстах; 2) загальнопредметні - належать до певної сукупності предметів або освітніх галузей та відрізняються високим ступенем узагальненості і комплексності; 3) предметні - часткові щодо названих вище, яких набувають у процесі вивчення певних предметів.

У Методичних рекомендаціях щодо розроблення стандартів вищої освіти спеціальні (фахові, предметні) компетентності визначаються як компетентності, що залежать від предметної області, та $€$ важливими для успішної професійної діяльності за певною спеціальністю. Вони визначають профріль освітньої програми та кваліфікацію випускника, роблять кожну освітню програму індивідуальною.

Предметну компетентність характеризують як ознаку високої якості його 
навчальних умінь, можливості установлювати зв'язки між набутими знаннями та реальною ситуацією та успішно використовувати свої уміння, сформовані протягом вивчення навчальної дисципліни [10].

У структурі предметної компетентності І. Чайковська (2005) виділяє три компоненти: когнітивний, діяльнісний, особистісний й зазначає, що компетентності не суперечать знанням, умінням і навичкам, вони передбачають осмислено їх використовувати. Ми цілком поділяємо думку дослідниці, акцентуючи увагу на тому, що, на нашу думку запропоновані компоненти предметної компетентності це внутрішні ресурси діяльності майбутнього лікаря.

Водночас В. Коновалова [4, с. 49] і Я. Кульбашна [5, с. 113] наголошують, що професійна діяльність лікаря дуже часто пов'язана з екстремальними умовами. Специфіка діяльності лікаря висуває особливі вимоги до рівня підготовки студентів у майбутній професійній діяльності, які з найбільшою ймовірністю зможуть успішно освоїти сучасні медичні знання і працювати у галузі тривалий час.

Предметну компетентність лікаря розглядаємо як готовність і здатність діяти в конкретній предметній області.

Як інтегрований результат пізнавальної діяльності студента в навчанні правознавства розглядає правову предметну компетентність О.Пишко. Знання й уміння 3 правознавства $€$ фрундаментом правової предметної компетентності майбутнього лікаря, оскільки без уявлень і знань про право не може фрормуватися готовність слідувати його нормам, ціннісне ставлення до нього та здатність чинити значимі правові діяння. Зазначимо, що предметні уміння передбачають розв'язання майбутнім лікарем пізнавальних завдань правового змісту в освітньому процесі та життєвих ситуаціях.

Ціннісна складова правової компетентності виявляється у ступені схвалення або неприйняття студентом правових норм. Пізнаючи правові явища й процеси, студенти співвідносять їх 3 власними уявленнями, потребами, життєвим досвідом, що, відповідно, викликає у них ціннісне ставлення до опанування медичним правознавством.

Предметну компетентність можна окреслити як сукупність набутих майбутнім лікарем знань з правознавства, умінь, особистісних якостей, необхідних для виконання певних дій з метою розв'язання проблем, ситуацій згідно приписів норм права.

Висновки. Таким чином, у медичному ЗВО у структурі предметної правової компетентності виділяємо: знання та розуміння теорій медичного правознавства; здатність сприймати нові знання в галузі медичного правознавства, уміння інтегрувати їх у цілісну систему власних знань; здатність зорієнтуватися на рівні спеціаліста в певній вузькій галузі медичного правознавства, яка лежить поза межами обраної спеціалізації; екстраполювати отримані знання у практичну діяльність. Перспективними напрямами подальших наукових розвідок $€$ розробка технології формування предметної компетентності майбутніх лікарів. 


\section{Використана література:}

1. Бондар С. Компетентність особистості інтегрований компонент навчальних досягнень учнів. Біологія і хімія в шиколі. 2003. № 2. С. 8-9.

2. Вступне слово до Проекту ТЬЮНІНГ - гармонізація освітніх структур у Європі. Внесок університетів у Болонський процес / Комітет з управління проектом Тьюнінг, 2006. 108 с.

3. Зимняя И. А. Компетентностный подход. Каково его место в системе современных подходов к проблемам образования? (теоретико-методологический подход). Высшее образование сегодня. 2006. № 8. C. 21-26.

4. Коновалова В. В. Формирование мировоззрения врача в высшем медицинском образовании. Alma Mater. Педагогика и психология. 2013. № 8. С. 48-52.

5. Кульбашна Я. А. Самостійна робота у формуванні професійної компетентності майбутніх стоматологів. Педагогічний процес: теорія і практика. 2013. Вип. 2. С. 111-118.

6. Маслова Т. Шляхи підвищення психолого-педагогічної компетентності викладачів. Новий колегіум: наук.-інформ. журнал. 2004. № 5/6. С. 59-63.

7. Петько Л. В. Виклики XXI століття для освітнього простору України. Наукові прачі [Чорноморського державного університету імені Петра Могили комплексу "Києво-Могилянська академія"]. Серія : Педагогіка : наук. журн. / Чорном. держ. ун-т імені Петра Могили; ред. кол. : О. П. Мещанінов (голова) [та ін.]. Миколаїв : Вид-во ЧНУ імені Петра Могили, 2017. Т. 303. Вип. 291. С. 10-14.

8. Петько Л В. Реалізація концепції підготовки магістрів в Україні для роботи в інклюзивному освітньому простор. Актуальні проблеми навчання та виховання людей в інтегрованому освітньому середовищі: Тр. XI Міжнар. наук.-практ. конф., листопад 2011 р. Ч. І. Київ : ВМУРЛ "Україна". 2011. С. 92-94.

9. Петько Л. В. Шляхи формування іншомовної соціокультурної компетенції студентів мистецьких спеціальностей ВНЗ у процесі фахової підготовки. Проблеми підготовки сучасного вчителя: зб. наук. пр. Уманського держ. пед. ун-ту імені Павла Тичини / [ред. кол.: Побірченко Н. С. (гол. ред) та ін.]. Умань : ПП Жовтий О.О., 2012. Вип. 6. Ч. 3. С. 57-62.

10. Пінчук О. П. Формування предметних компетентностей учнів основної школи в процесі навчання фізики засобами мультимедійних технологій: автореф. дис. ... канд. пед. наук / Національний педагогічний університет імені М. П. Драгоманова. Київ, 2011. 20 с.

11. Професійна освіта. Словник : навч. пос. / уклад. С. У. Гончаренко та ін.; за ред. Н. Г. Ничкало. Київ: Вища шк., 2000. 380 с.

12. Татур Ю. Г. Компетентность в структуре модели качества подготовки специалиста. Высшее образование сегодня. 2004. № 3. С. 20-26.

13. Тернопольская В. И., Бакулина О.С. Особенности формирования профессиональной компетентности будущих специалистов по налогообложению и таможенному делу. International scientific journal "Progress". № 1-2. Tbilisi: International Publishing House "Progress". 2018. P. 94-97.

14. Тернопільська В. І., Дерев'янко О. В. Визначення критеріїв сформованості професійної компетентності майбутніх гірничих інженерів. Наук. часопис НПУ імені М. П. Драгоманова. Серія 5: Пед. науки. 2012. Вип. 31. С. 264-267.

15. Тернопільська В. І. Структура професійної компетентності майбутнього фахівця. Науковий вісник Мелітопольського держ. пед. ун-ту. Серія: Педагогіка. 2012. № 9. С. 208-213.

16. Тернопільська В. І. Моделювання процесу формування самоосвітньої компетентності майбутніх фахівців. Педагогічна освіта: теорія і практика. Психологія. Педагогіка. 2016. № 25. С. 16-22.

17. Pet'ko L. Preparing higher school graduates in foreshortening of leader competencies for 2020. Topical questions of contemporary science: Collection of scientific articles. Aspekt Publishing of Budget Printing Center, Taunton, MA 02780, United States of America, 2017. Pp. 467-472.

18. Specters J. Michael de Teja Ileana. ERIC Clearinghouse on Information and Technology Syracuse NY. Competencies for Teaching. ERIC Digest. Competence. Competencies and Certification. 2001. Pp. 1-3.

19. Ternopilska V. I., Kovalynska I. V. A survey of multicultural education in Ukraine: state approach. Science and practice: Collection of scientific articles. Thorpe-Bowker, Melbourne, Australia, 2016. Pp. 256-259.

20. Ternopilska V. I., Brovko K. A. Corporate culture of personality: psychological aspects. Topical issues of contemporary science: Collection of scientific articles. C.E.I.M., Valencia, Venezuela, 2017. Pp. 176-178. 


\section{References:}

[1] Bondar S. (2003). Kompetentnist osobystosti intehrovanyi komponent navchalnykh dosiahnen uchniv. Biolohiia i khimiia v shkoli. No. 2. Pp. 8-9.

[2] Vstupne slovo do Proektu TIuNINH - harmonizatsiia osvitnikh struktur u Yevropi. Vnesok universytetiv u Bolonskyi protses (2006). Komitet $\mathrm{z}$ upravlinnia proektom Tiuninh. $108 \mathrm{p}$.

[3] Zimnyaya I. A. (2006). Kompetentnostnyiy podhod. Kakovo ego mesto v sisteme sovremennyih podhodov $\mathrm{k}$ problemam obrazovaniya? (teoretiko-metodologicheskiy podhod. Vyisshee obrazovanie segodnya. No. 8. Pp. 21-26.

[4] Konovalova V. V. (2013). Formirovanie mirovozzreniya vracha v vyisshem meditsinskom obrazovanii. Alma Mater. Pedagogika i psihologiya. No. 8. Pp. 48-52.

[5] Kulbashna Ya. A. (2013). Samostiina robota u formuvanni profesiinoi kompetentnosti maibutnikh stomatolohiv. Pedahohichnyi protses: teoriia i praktyka. No. 2. Pp. 111-118.

[6] Maslova T. (2004). Shliakhy pidvyshchennia psykholoho-pedahohichnoi kompetentnosti vykladachiv. Novyi kolehium. No. 5-6. Pp. 59-63.

[7] Petko L. V. Vyklyky XXI stolittia dlia osvitnoho prostoru Ukrainy. Naukovi pratsi ChNU: nauk. zhurnal. Mykolaiv: Vyd-vo ChNU imeni Petra Mohyly, 2017. T. 303. Issue 291. Pp. 10-14 (Pedahohika).

[8] Petko L V. (2011). Realizatsiia kontseptsii pidhotovky mahistriv v Ukraini dlia roboty v inkliuzyvnomu osvitnomu prostori. Aktualni problemy navchannia ta vykhovannia liudei $v$ intehrovanomu osvitnomu seredovyshchi: Tr. XI Mizhnar. nauk.-prakt. konf., lystopad 2011 r. Part. I. Kyiv: VMURL "Ukraina". Pp. 92-94.

[9] Pet'ko L. V. (2014). Shljahy formuvannja profesijno sprjamovanogo inshomovnogo navchal'nogo seredovyshha dlja majbutnih sociologiv $\mathrm{v}$ umovah universytetu (na prykladi special'nosti 6.030101 "Sociologija"). Naukovi zapysky. Vol. CXX (120). Pp. 101-110.

[10] Pinchuk O. P. (2011). Formuvannia predmetnykh kompetentnostei uchniv osnovnoi shkoly v protsesi navchannia fizyky zasobamy multymediinykh tekhnolohii: avtoref. dys. ... kand. ped. nauk / Natsionalnyi pedahohichnyi universytet imeni M. P. Drahomanova. Kyiv, 2011. 20 p.

[11] Profesiina osvita. Slovnyk (2000) / ukl. Honcharenko S. U. Kyiv: Vyshcha shk. 380 p.

[12] Tatur Yu. G. (2004). Kompetentnost v strukture modeli kachestva podgotovki spetsialista. Vyisshee obrazovanie segodnya. No. 3. Pp. 20-26.

[13] Ternopolskaya V. I., Bakulina O. S. (2018). Osobennosti formirovaniya professionalnoy kompetentnosti buduschih spetsialistov po nalogooblozheniyu i tamozhennomu delu. International scientific journal "Progress". No. 1-2. Pp. 94-97.

[14] Ternopilska V. I., Derevianko O. V. (2012). Vyznachennia kryteriiv sformovanosti profesiinoi kompetentnosti maibutnikh hirnychykh inzheneriv. Nauk. chasopys NPU imeni M. P. Drahomanova. Issue 31. Pp. 264-267.

[15] Ternopilska V. I. (2012). Struktura profesiinoi kompetentnosti maibutnoho fakhivtsia. Naukovyi visnyk Melitopolskoho derzhavnoho pedahohichnoho un-tu. Seriia: Pedahohika. Series: Pedagogy. No. 9. Pp. 208-213.

[16] Ternopilska V. I. (2016). Modeliuvannia protsesu formuvannia samoosvitnoi kompetentnosti maibutnikh fakhivtsiv. Pedahohichna osvita: teoriia i praktyka. Psykholohiia. Pedahohika. No. 25. Pp. 16-22.

[17] Pet'ko L. Preparing higher school graduates in foreshortening of leader competencies for 2020. Topical questions of contemporary science: Collection of scientific articles. - Aspekt Publishing of Budget Printing Center, Taunton, MA 02780, United States of America, 2017. Pp. 467-472.

[18] Specters J., Ileana Michael-de Teja. (2001). ERIC Clearinghouse on Information and Technology Syracuse NY. Competencies for Teaching. ERIC Digest. Competence. Competencies and Certification. Pp. 256-259.

[19] Ternopilska V. I., Kovalynska, I. V. (2016). A survey of multicultural education in Ukraine: state approach. Science and practice: Collection of scientific articles. Pp. 256-259.

[20] Ternopilska V. I., Brovko K. A. (2017). Corporate culture of personality: psychological aspects. Topical issues of contemporary science: Collection of scientific articles. Pp. 176-178. 
Хмиль И. Ю. Проблема формирования предметной компетентности будущих врачей в педагогической теории.

В статье проведен анализ научных трудов ученых по проблеме формирования предметной компетентности будущих врачей. На основе изучения научных работ показаны достижения, недостатки и перспективы затронутой проблемы. Охарактеризована компетентность как способность личности воспринимать и отвечать на индивидуальные и социальные нужды, комплекс отнотетий, ценностей, личностное качество личности основанное на знаниях, умениях. Предметная компетентность рассматривается как интегрированный результат учебной деятельности студентов, составляюший его саморазвитие и самосовершенствование, важное средство повышения профессиональной готовности специалиста. Отметим, что специфика врача предъявляет особые требования к уровню подготовки студентов в будущей профессиональной деятельности, которые смогут успешно освоить современные медицинские знания и работать в области длительное время. Отмечено, что знания и умения по правоведению являются фундаментом правовой предметной компетентности будущего врача, поскольку без знаний о праве не может формироваться готовность следовать его нормам, ценностное отномение к нему и способность вести правовые действия.

Предметную компетентность характеризуется как совокупность приобретенных будущим врачом знаний по правоведению, умений, необходимых для выполнения определенньх действий с иелью решения проблем, ситуаций согласно предписаний норм права.

Ключевые слова: компетентность, предметная компетентность, образование, студент, будущий врач, правоведение, медищинское правоведение.

\section{theory. \\ KHMIL IRYNA. The problem of forming subject competence in future doctors in pedagogical}

The article analyzes the scientific works by scientists on the problem of forming subject competence in future doctors. Based on studying scientific works the author presents the achievements, disadvantages and prospects this problem. Competence is characterized as an ability of a person to perceive and respond to individual and social needs, a set of attitudes, values and personal quality based on knowledge and skills.

The article studies pedagogical components of the subject competence formation in future doctors. Main aspects of future doctors' professional training at higher medical educational institutions are also described. The concept of forming subject competence in a specialist is suggested.

The subject competence is considered as an integrated result of students' educational activity, as a component of their self-development and self-improvement, as an important means of increasing the professional readiness of a specialist. Stressed that a problem of subject competence formation in future doctors is one of the most important in the field of professional medical education. In the 21st century, the health-law specialty has broadened beyond malpractice and advocacy for medical professionals' rights. As the field has evolved to handle a greater number of areas of law, the need for qualified attorneys has also increased. Medical lawyers do the same kind of work as other lawyers, but focused on some aspect of the medical industry or individual or public health. Thus the subject competence can be defined as a complex of knowledge acquired by a future doctor in the field of law, skills, personal qualities necessary for performing certain actions in order to solve problems, situations according to the rules of law.

The structure of subject legal competence covers knowledge and understanding of the theories of medical law; the ability to acquire new knowledge in the field of medical law, the ability to integrate them into a coherent system of their own knowledge. law.

Keywords: competence, subject competence, education, student, future doctor, jurisprudence, medical 